Илија Б. Зиндовић

Универзитет Привредна академија

Нови Сад
УДК: 343.352(497.11)

Преїледан рад

Примљено: 31. 1. 2012.

\title{
Владан Станковић
}

Институт за политичке студије

Београд

\section{"ЛЕГАЛИЗОВАНИ" ОБЛИЦИ КОРУПЦИЈЕ У СРБИЈИ - АНОМИЧНА СТАҢА ДРУШТВЕНЕ ЕНТРОПИЈЕ}

Предметі овоі̄ истираживања биће феномени "леїализованих" облика коруйције. Овај назив дали смо свим оним облицима аномичних друшиевених йонашана која измичу инкриминацији, йачније не ӣодйадају ӣод удар закона, а доводе до увећа-

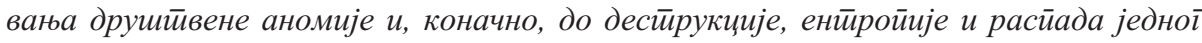

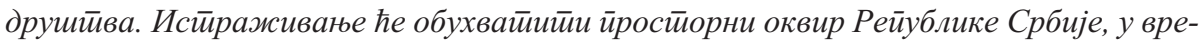
менском ӥериоду од 1990. іодине до данас, са найлашеним осврйом на раздобље од 2001. іодине до данас, и иррайи временски оквир йранзицие из соџијализма у йосй-

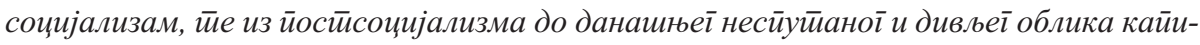
йализма. Мет̄оди који су у истиражсивану коришћени су: сочиолошки (мейод йо-

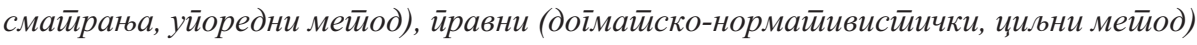
и лоїички мет̄оди іенерализације и конкретиизаџије. Циљ истираживања је да се укажее на йојавне облике коруӣције који до сада из различиитих разлоїа нису инкрими-

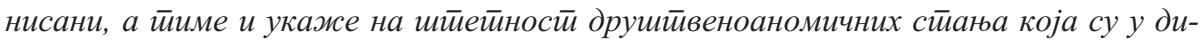

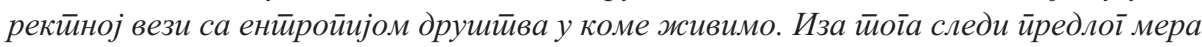
за укланане ових ииеиеиних йојавних феномена који су у іраничној обласиии сочиолоїuje и йрава.

Кључне речи: коруйщија, друшӣвена аномија, инсиичӣиције, йравосуђе, Србија

$$
* * *
$$

У овом раду биће речи о утицају "легализованих" облика корупције на изазивање друштвене аномије која води у свеопшту девастацију друштва. Ово ентропично стање очитава се како у помањкању моралних вредности друштвених актера тако и у материјалном пропадању друштва, које изазивају "легализовани" облици корупције, а са њом и свеопшта аномија. Полазећи од тога да "легална" корупција, иако contradictio in adjecto, представља несанкционисане злоупотре- 
Илија Б. Зиндовић, Владан Станковић, „Легализовани“ облици корупције у Србији...

бе које доводе до политичке и материјалне моћи, покушаћемо најпре да дефинишемо предмет истраживања који се креће у опсегу: "легализовани" облици корупције > друштвена аномија > друштвена ентропија. ${ }^{1}$

\section{1. Одређење предмета разматрања}

Да бисмо истражили узрочност "легализованих" облика корупције, која могу да доведу до свеопштег стања друштвене ентропије, неопходно је да дефинишемо понајпре појам коруйщије (односно "легализоване" корупције), као и појам друиитвене аномије.

1. Појам коруйција долази од lat. corruptio што значи: подмитљивост, поткупљивост, поквареност. ${ }^{2}$ Оно што представља genus proximum појма корупција јесте йонашање, али то може бити и радюа службеноі лица. ${ }^{3}$ Још понегде се среће дефиниција корупције као злоупотреба јавне власти. Тако за Зорана Милосављевића "корупција представља сваку злоупотребу положаја од стране државног службеника или особе која врши одређену јавну функцију, а која за циљ има личну или материјалну корист" (Милосављевић, 2011: 175). За економисту Предрага Алексића: "Корупција је понашање засновано на заобилажењу редовних путева у решавању пре свега личних, а затим и друштвених проблема на уштрб и штету других појединаца и заједница." (Aleksić, 1975: 615) Међутим, ово прешироко тумачење појма биће сужавано. Тако неки аутори корупцију доводе директно у везу са: ерозијом јавне етике, губитком легитимног статуса државе (као отелотворења општег интереса), као и разводњавањем вредности заједнице кроз трку за профитом и одбрану себичних приватних интереса. ${ }^{4}$ Једна од традиционалних дефиниција корупције је и: "злоупотреба јавне власти зарад приватне добити" (Gredelj, 2007: 260). Слична је и дефиниција према којој корупција представља "недостатак интегритета или поштења (посебно осетљивост на мито), коришћењем позиције поверења за непоштени добитак." 5 За социолога Стјепана Гредеља

1 Тако нпр. социолог Слободан Вуковић наводи: "Један од проблема непоштовања правних норми је, такође, када у једном друштву у дужем периоду у некој области постоји одсуство правне регулације." (Вуковић, 2004b: 514)

2 "U suštini ovog ponašanja leži pokvarenost, neiskrenost, podmićivanje, potplaćivanje." (Aleksić, 1975: 615)

${ }^{3}$ О вези понашања и положаја пише Вито Танци (Vito Tanzi). Према њему, на примеру корупције види се индивидуалан интерес који угрожава друштво и ствара велику забринутост (Tanzi, 2000: 148).

4 "On the other hand, those who are not convicted of the state's intrinsic perversity of the market's unquestionable merits strees another aspect: the erosion of public ethics, the loss of the state's legitimate status as the incarnation of the general interest, and the dilution of communal values through the pursuit of profit and defence of selfish private interests." (Mény, 1996: 309)

5 "(...) lack of integrity or honesty (especially susceptibility to bribery); use of a position of trust for dishonest gain." (Laguna, 2011: 3) 
корупција "настаје тамо где постоји комбинација могућности и склоности" (Gredelj, 2007: 260). Слично налазимо и на другим местима где се под корупцијом "подразумева незаконито коришћење друштвеног и државног положаја и моћи ради стицања сопствене користи" (Корупција, 2011). Слично и у Rječniku finansijskih pojmova, према коме корупција подразумева предузимање извесних јавноправних радњи у циљу стицања добити (Korupcija, 2012). Поред ових постоје још уже дефиниције корупције које имају више институционални карактер. Тако је, према Неју, "корупција девијантно понашање делатника јавне управе (изабраних или именованих) које није у складу с њиховим задацима по службеној дужности, а примењује се у циљу стицања приватног богатства или статуса појединца, уже породице или повезане групе људи" (Nye, 1967: 417). Како год било битна обележја корупције огледају се у: приступима бенефитима и избегавању трошкова, одобравању послова за које је неопходна дозвола, екстрадобити, бржем и/или квалитетнијем добијању услуга, приступима поверљивим информацијама, заштити од конкуренције или наношењу штете истој, трговини утицајима или сукобу интереса, прихватању поклона, непотизму, вези са организованим криминалом, кронизму (привилеговању по страначкој линији), кршењу професионалне етике (изнуде у здравству, високом образовању и сл).

2. О аномији, као посебном стању друштва, у социолошкој теорији писали су многи значајни социолози почев од Конта, преко Маркса, Диркема, Парета, Вебера, до Парсонса и савремених социолога. Из радова првих социолога, Конта и Маркса, може се тек назрети њихов доживљај аномије као друштвеног стања. Огист Конт у аномији види потенцијалну опасност да друштво отклизи у хаос и насилне промене. Са друге стране, за Маркса и његове следбенике друштвена аномија је показатељ да је класна свест владајуће класе ослабила и да је то прилика да се револуционарно успоставе нове моралне вредности, које ће одговарати новонасталом стању производних односа. ${ }^{6}$ Иако су о аномији писали многи социолози пре Емила Дирекема, тек је сам Диркем дефинисао појаву аномије одредивши је као: безакоюе, што се са грч-

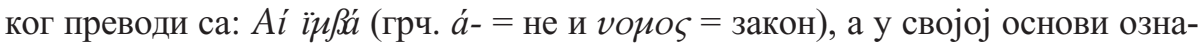
чава: "одсуство закона или безакоње, односно стање неделотворности, распада или непостојања друштвених норми" (Tripković, 2007: 22). Друштвена је аномија, дакле: помањкање, суспензију или неефикасност друштвених норми, закона, прописа и вредности које доводи до дезорганизације и дестабилизације друштва, као и до конфузије у моралној свести појединца, а често узрокују

6 "To nastaje zbog toga, što su pravna pravila zastarjela jer su na osnovu novih, viših i općijih objektivnih zakonitosti nastala nova moralna shvatanja o dobru i zlu i novi oblici nemorala i poroka o kojima stara pravna pravila ništa ne znaju. To se uvijek dešava u smijeni društveno-ekonomskih poredaka ili društveno-ekonomskih formacija." (Legradić, 1968: 39) 
Илија Б. Зиндовић, Владан Станковић, „Легализовани“ облици корупције у Србији...

и делинквентно понашање. ${ }^{7}$ Диркем је аномију везивао и за друштвену транзицију када више не важе раније норме и традиционалне вредности, а нове још нису успостављене, што доводи до пометње и дезоријентације чланова друштва у трагању за социјално пожељним обрасцима понашања. 8 "Патолошка, аномична, подела рада се, по Диркему, јавља онда када пребрзе промене друштвеног система теже да створе нове функције, пре него што оне могу бити регулисане. Због тога долази до сукоба, конкуренције, који нису под надзором адекватних облика друштвене моћи. Норме понашања су неодговаpajуће, контрадикторне, нелегитимне, па су чланови друштва без праве оријентације, препуштени сами себи." (Inđić, 1982: 9)9 ${ }^{9}$ Аномично стање доводи до болести друштва, до његове ентропије, у коме, сада, владају нека нова, аутономна правила. ${ }^{10}$

На његова истраживања, нешто касније, надовезаће се Вилфредо Парето који у својој теорији елита, полазећи од реалних моћи у једном друштву, указује да елитама не припадају племенити већ вешй $u$, и да управо они користећи хаотичност и безакоње друштвених околности задобијају статус елите, управљајући ресурсима једног друштва. ${ }^{11}$ Аномични контекст друштвеног окружења тако је превео органске везе вредносних поступака на интересне релације индивидуалних сналажења (ситауциони оквир).

Још касније, код функционалиста, веза аномије и ентропије је још непосреднија и лако уочљива. Тако је друштвена аномија означена као "контрадикторност, неусклађеност функционирања неког система односно поља равнотеже сила, услијед чега се нарушава регулативна способност самог система и могућност контроле у оквиру њега самог. Аномија изразито појачава ентропију система, деструктурира га и деинституционализира, те у крајњем доводи до слома поретка и правилности" (Bosanac, 1977: 26). Код Мертона је несклад између задатог циља и средстава која актеру-у-ситуацији стоје на располагању основа за истраживање и

\footnotetext{
7 "Anomie is defined as normleness or lack of norms, but we have to recognize, with Olsen, that such a condiction rarely if ever exists in any society." (Kim, 2003: 3)

8 За Диркема аномија представља "слом законских и моралних правила" (Lukes, 1985: 207).

9 "Ovo stanje nastaje ne samo pri naglim promenama privrednog sistema (industrije, trgovine) i krizama koje njihovo haotično delovanje izaziva, nego i pri svakom izuzetnom zbivanju u društvu, njegovim katastrofama, neujednačenom rastu, naglim zaokretima u političkom i vrednosno-kulturnom sistemu." (Inđić, 1982: 10)

10 "... l' anomie est définie comme le mal dont souffre une société dans son ensemble par défaut de règles morales et juridiques qui organisent son économie." (Groupe par, Anomie, 1970: 25)

11 "Некој вештој вуцибатини која уме да вара људе, а да при томе не буде кажњена, даћемо 8, 9 , па чак и 10 , већ према броју који је очерупала и према количини новца који је успела да им извуче. Стога, дакле, наставља Парето: одвојимо класу људи који имају највише показатеље у својој грани делатности и назовимо их елитом." (Тартаља, 1976: 176)
} 
аномичног стања. ${ }^{12}$ "Роберт Мертон сматра да је за настанак аномије битна тензија која се јавља код појединаца или друштвених група, онда када се општеприхваћене норме и вредности налазе у раскораку са друштвеном стварношћу."13

У многим сегментима, понекад и у намерно непрецизној правној регулативи, а у не малом броју случајева и због политичког утицаја на правосудне органе, корупција остаје несанкционисана. Тако "легална" корупција постаје правило... Природно, а и законско, неправо постаје надзаконско право. ${ }^{14} \mathrm{У}$ техничким и природним наукама таква би се појава палијативним мерама одстранила, како би целина могла да опстане (естетски или егзистенцијално). У друштвеном животу овакве нежељене појаве доводе до друштвене аномије, кроз: деструкцију правног система, задржавање економског стања на ниском ступњу раста и разво$\mathrm{ja}$, довођење у питање основа демократског политичког система. Лечење овакве појаве је и дуготрајно и болно. ${ }^{15}$

Последице, нарочито овог вида корупције, изразито су негативне. "Она својим утемељењем у друштву, отежава афирмацију владавине права, доводи до неповерења грађана у институције система, дестабилизује привредни развој, подстиче неједнакост међу људима и наравно негативно утиче на друштвену консолидацију и општу сигурност. Упоредо са тим, корупција руши основне људске вредности и ремети установљену природну скалу цивилизацијских достигнућа, моралних и других вредности." (Заграђанин, 2009: 157)

\section{2. „Легализовани“ облици корупције у Србији ${ }^{16}$}

У зависности од тога како се остварује, могу се разликовати три основна типа корупције: корупција ради остваривања права (или његовог убрзања), коруп-

12 "L'anomie résulte du conflit que subit l'individu entre les buts proposés par la société et les moyen légitimes pour y acceder qui sont à sa disposition, en fonction de sa place dans la stratification sociale." (Groupe par, Anomie, 1970: 25)

13 "Prema njegovom mišljenju, devijantno ponašanje je simptom provalije koja postoji između kulturom nametnutih aspiracija i društveno strukturisanih mogućnosti." (Tripković, 2007: 22)

14 При томе Радбрух под законским правом подразумева оно што је у складу са природним правом (Radbruh, 1980: 50-57).

15 "На основу до сада изнетих резултата истраживања видели смо да је корупција широко распрострањена и да је постала готово јавна ствар. То значи да се новац или услуга тражи или очекује без имало стида и зазора. Готово све се плаћа, изнуђује, тражи или очекује новац, контра услуга или пак снисходљиво даје ситан или крупан поклон да би се одобровољио..." (Вуковић, 2001а: 10)

16 Проблемима корупције у Србији бавила се неколицина аутора. Међу њима истичу се монографије Слободана Вуковића (Vuković, 2005; Вуковић, 2007) и зборник радова Бориса Беговића (Беговић и др., 2007). Уз то немали број научних истраживача објавио је радове на тему корупције у Србији: van Duyne, Stocco, Milenović (2009); Шуковић (2006); Grk (2004); Nikolić (2011); Станојевић, Димовски (2011); Jovašević (2011); Ракић (2010); Đurić (2009); Станковић (2011). 
Илија Б. Зиндовић, Владан Станковић, „Легализовани“ облици корупције у Србији...

ција ради кршења закона, и корупција ради не доношења, мењања или недоследне примене закона и подзаконских аката. Овај последњи облик корупције је и најперфиднији, тешко се открива, активности везане за њу су углавном легалне (нису санкционисане), а иза ње најчешће стоје моћне финансијске и политичке групације које су у тесној вези са влашћу. Државне институције у борби против овог вида корупције углавном губе битку, без обзира у којој сфери друштвеног живота се она јавља.

\section{1. Привреда и уйрава}

Због административног управљања привредом, постојања система увозних и извозних дозвола, неизграђености система тржишне конкуренције, корупција у овој сфери друштва егзистира као системска ствар. Демократске промене и антикорупцијска стратегија од 2001. године исходовале су низ како директних тако и индиректних мера у циљу сузбијања овог друштвеног зла. Донето је низ законских прописа, али евидентно је да су на овом пољу најбоље резултате дале тзв. индирекӣне мере везано за дерегулацију и либерализацију спољне трговине. Тако је изменом Закона о спољнотрговинском пословању (2000, 2002, 2005) укинут велики број административних препрека за обављање трговине (увозне и извозне дозволе и контигенти). Поступак увоза и извоза је знатно поједностављен, што је на индиректан начин елиминисало услове за корумпирање администрације у овој области привређивања. Умањене су царинске стопе и исте су приближене просеку царинских стопа осталих транзиционих привреда. Регистрација привредних субјеката је измештена из трговинских судова и пренета у надлежност Агенције за привредне регистре на републичком нивоу. Поступак је поједностављен, а тиме је и отклоњена различитост тумачења у погледу услова за регистрацију. Донет је Закон о привредним друштвима (2004), који је определио ниске оснивачке улоге за оснивање и регистрацију. Донет је Закон о заштити конкуренције $(2005,2009)$, при чему је створена основа за укидање монопола који су представљали посебну основу за „легалну“ корупцију. Уведен је нови обједињени систем контроле и наплате јавних прихода. ${ }^{17}$ Уведен је буџетски систем, при чему је установљена јасна буџетска процедура јединствена за све нивое власти, што је омогућило постојање ажурности дневних података о врстама расхода и корисницима републичког буџета. Преносом средстава на рачуне буџетских корисника измењена је улога Министарства финансија у извршењу буџета. При томе ваља нагласити да је, и поред свих ових позитивних новина, ство-

${ }^{17}$ Надлежност за утврђивање, прикупљање и контролу јавних прихода имале су три међусобно потпуно некоординисане институције: Републичка управа јавних прихода (РУЈП), Финансијска полиција (ФП) и Завод за обрачун плаћања (ЗОП). 
рен највећи и главни генератор корупције: укидањем Завода за обрачун и плаћања (ЗОП-а) изгубила се и могућност контроле токова новца у земљи, па је створен прави шиеекуланйски Елдорадо за свакојаки финансијски промет на тржишту.

Уз то, некомплетна и непрецизна правна регулатива у овој материји створила је ситуацију да поједини буџетски корисници нису били обавезни да дозначена средства троше за тачно одређене намене, већ су са њима могли слободно располагати. Та средства су полагали у банке на рачун за штедњу и добијали одговарајуће камате. Тиме се стварала апсурдна ситуација да се код државе, у њеном буџету појављује дефицит, док корисници буџетских стедстава имају вишак средстава. Даље, поједини политички челници (углавном министри и други управљачи републичког ранга), средства су користили ненаменски - мимо закона, а услед недовољне контроле ревизорске службе (што због политичког утицаја, што због недовољног броја запослених ревизора), санкционисање је изостало. У неким случајевима поднете су прекршајне пријаве. Поједини поступци и поред дужег протока времена још нису окончани, а у случајевима где је прекршајни поступак окончан изречене су изузетно ниске новчане казне. Тиме је дат подстрек за даљу неометану корупцију у тој сфери. Посебан проблем јавио се у политици акциза. Због малог прилива новца и спорог пуњења буџета, за поједине увозне производе одређене су високе акцизе (нпр. код увоза нафте). То има негативно повратно дејство, јер "високо учешће акциза у продајној цени ствара велике подстицаје за шверц и корупцију пре свега у царинској служби" (Беговић и др., 2007: 111).

\section{2. Аїенције и јавна ӣредузећа}

Тенденција ка изградњи ефикасне управе настојање је сваке озбиљне власти. То подразумева стручан и не гломазан чиновнички апарат. Након октобарских промена 2000. године Србија, уместо да том проблему посвети пуну пажњу, кренула је у супротном смеру. Кроз систематизацију радних места, смањењем истих, нова власт је отпустила непожељне кадрове, без обзира на њихову стручност, да би након тога новом систематизацијом примила нове кадрове искључиво по политичкој линији, уопште не водећи рачуна о њиховој стручности. Уместо рационализације управе и смањења запослених дошло је до повећања њиховог броја, а стручност нових кадрова ни издалека није проверавана. Када је ЕУ, због потписивања Сйоразума о сӣабилизацији и йридружсиваюу, назначила да се мора редуцирати број запослених у управи, Влада је оснивањем одређених агенција и поверавањем одређених послова истим, део особља пребацила у те агенције. На овај је начин власт "куповала поверење" новозапослених. Број агенција се неконтролисано ширио, па их сада у Србији има преко 130 и углавном се финансирају из буџета. Оно што је посебно значајно код појединих агенција је 
Илија Б. Зиндовић, Владан Станковић, „Легализовани“ облици корупције у Србији...

чињеница да им је дато право да на један посебан начин самостално одређују висину зарада својим запосленим, иако су и фактички и формално државне институције. То је еклатантан пример приватизације услуга државног сектора (usurpatio Res publicae). Та допунска средства се по правилу обезбеђују кроз прописивање и наплату високих такси, које су понекад толико високе да нису примерене ни за земље са знатно вишим стандардом. ${ }^{18}$ Тако запослени у тим агенцијама легално стичу право на високе зараде чија је висина непримерена, док су примања запослених у сличним секторима вишеструко мања. Све то представља „легалан“ вид корупције. Инспекцијски органи у смислу контроле и промене таквог стања немају никакве ингеренције. Ако је пракса да таксе представљају посебну врсту пореза, да су по правилу у ниским износима и да се њихова уплата прослеђује у буџет, нема разлога да се тако не поступа и у оваквим случајевима. Тиме још увек не би важила изрека да је у Србији битно где радиш, а не шта радиш. Одређене агенције су овлашћене да издају сертификате и лиценце. При томе се на посебан начин (или кроз изгласавање закона или кроз кроз коришћење овлашћења да саме определе висину таксе) те накнаде наплаћују у енормно високим износима јер је њихова висина далеко већа од износа накнада које се наплаћују у најразвијенијим земљама. ${ }^{19}$ Поставља се логично питање: која је висина вредности норме часа опредељена у овом случају?

Слична ситуација је и са Народном банком Србије (НБС). По уставу и закону ова институција има одређену самосталност. Та самосталност се огледа и у чињеници да она опредељује параметре за зараде својих запослених, па и најви-

18 Тако је Законом о заштити конкуренције (2005) у чл. 52. било прописано да о жалби на решење Комисије одлучује надлежни -а то је Врховни суд У чл. 48 Закона је било прописано да члан Савета има зараду односно накнаду у висини судије Врховног суда. Очигледна је нелогичност да члан Савета има исту зараду (или накнаду) као и члан другостепеног органа који одлучује о жалби. Ако је чињеница да су Закон о заштити конкуренције конципирала лица која су након усвајања закона изабрани за чланове савета али без заснивања радног односа, онда таква регулатива и не чуди. Без обзира на нелогичност и неморалност таквих одредби оне су „легалне“. Доношењем новог Закона о заштити конкуренције 2009. године (2009), ситуација је постала још чуднија. Према чл.29. Закона, прописано је да председник Комисије и чланови Савета имају право на зараду односно накнаду за рад у Комисији, а чл.77.ст.с. да до избора председника и судија Врховног касационог суда, плата председника Комисије, односно чланова Савета, утврђује се у висини плате председника односно судија Врховног суда. Сада о жалби на решење Комисије одлучује Управни суд, који је нижег ранга од Врховног касационог суда па тиме и положај судија тих судова. Мађутим, редакторима новог закона није било необично да у закону остану одредбе које председнику Комисије и члану Савета омогућују већу накнаду од накнде тј, зараде лицима која раде у органу(суду) који одлучује о жалби тј као дгугостепени орган. При томе, чланови Савета који нису у сталном радном односу у Савету (професори са факултета), немају обавезу сталне присутности, већ долазе повремено када су заказане седнице Савета.

19 Примера ради, може се навести Агенција за хемикалије, код које се за регистрацију хемијског производа плаћа такса у висини од 2000 евра. 
ших руководилаца. Тако се дошло у парадоксалну ситуацију да гувернер НБС (не заостају ни вицегувернери) има месечну зараду преко 6.500,00 евра, док зарада Председника Републике износи нешто више од 1.500,00 евра. Овај потез запослених у НБС често се образлаже оствареним зарадама НБС на међубанкарском тржишту, што је (у најмању руку) неуобичајено право које је једна централна банка за себе прибавила. "Легалност" овакве корупције је очигледна.

Функционисање јавних предузећа засновано је на принципу потпуне политизације. Положај директора се узурпира кроз политичку селекцију кадровања оних странака које су на власти. На исти начин се формира и управни одбор (коja је апсолутно непотребна институција). Чланови управних одбора имају право на одређене накнаде, иако је правни основ тог права врло дискутабилан. Ако постоји директор јавног предузећа, који треба да одговара оснивачу за свој рад, чему уопште постојање управних одбора и расипање новца на исплате њиховим члановима.

\section{3. Привайизачија и субвенције}

У свим земљама транзиције процес приватизације је био врло болан. Разлог томе је недовољна изграђеност институција и неискуство у погледу спровођења поступка и контроле након спроведеног поступка приватизације. Од 1997. године Србија је више пута мењала стратегију приватизације што је било праћено и законским прописима (измене Закона о приватизацији из 2001. године су биле 2003, 2005, 2007, 2010). Ипак поред свих његових дотеривања Закон није успео да на адекватан начин заштити мањинске акционаре.

У погледу уговорних одредби и отуђења капитала предузећа, законодавна решења су неадекватна. Према чл.41ж. предвићено је да купац капитала, отуђење имовине предузећа може вршити само по предходно прибављеној сагласности Агенције за приватизацију и то под одређеним законом прописаним условима. Међутим, тумачење је било да се то односи само на непокретну имовину. Покретна имовина је остала незаштићена, а њена вредност у одређеним случајевима може бити изузетно висока. Такође, законом није предвиђена забрана оптерећења непокретности које чине капитал приватизованог предузећа. Нови власници често код домаћих комерцијалних банака узимају високе кредите, а као средство обезбеђења дају под хипотеку непокретности предузећа. Путем фиктивних уговора где се наводно захтева авансно плаћање, новац од добијеног кредита се пребацује у иностранство. Тај новац и новац добијен продајом покретних ствари прелази вредност почетних уплаћених рата предвићених уговором о приватизацији. Након тога се не уплаћује следећа рата и уговор се раскида, али купац није ништа изгубио већ је зарадио. Након раскида уговора о приватизацији та предузећа, по правилу, одлазе под стечај. Губитници су и држава и радници. Иако је 
Илија Б. Зиндовић, Владан Станковић, „Легализовани“ облици корупције у Србији...

тај проблем више пута потенциран на разним научним и стручним скуповима где су редовно били присутни и представници Агенције за приватизацију, измене Закона о приватизацији у циљу побољшања правне регулативе у том делу није вршена. Законодавна празнина (намерна или ненамерна) и даље пружа добру подлогу за "легалну" корупцију.

У правно изграђеним системима, питање државних субвенција регулисано је прописима из области заштите конкуренције. На субвенције се гледа као на посао којим држава не треба да се бави јер се тиме нарушава конкуренција. Али, у појединим периодима кризе, да би се одређени сектори опоравили, држава се опредељује на давање субвенција. У начелу, у томе нема ничег лошег, а у Србији су субвенције даване предузетницима преко Фонда за развој, пољопривредницима преко Министарства пољопривреде, за решавање стамбених потреба преко Националне корпорације за осигурање стамбених кредита, за започињање посла личним радом и покретање сопственог бизниса преко Националне службе за запошљавање. Међутим, оваква давања, било бесповратна или у облику повољних кредита, стварају основу за корупцију. Критеријуми за добијање (додељивање) ових давања никада не могу до те мере бити тако добро прецизирани, а да не пружају могућност некажњиве злоупотребе. Осим тога, била је приметна и чињеница да је у Србији процедура оваквих давања (субвенције и кредити) била обојена политичком (партијском) припадношћу корисника. У таквим случајевима "легитимитет" је односио превагу над "легалитетом".

\section{4. Јавне набавке}

По својој природи, јавне набавке су једна од области које су највише подложне корупцији. (Беговић и др.,2007:112). Разлог тога је двојак: ради се о трансферу државних средстава ка приватном сектору и о том трансферу одлучују државни службеници и политичари. Закон о јавним набавкама (2002), у циљу побољшања регулативе, претрпео је више измена $(2003,2004,2005)$. Међутим, и поред свих настојања да се ова област адекватно уреди, могућности за корупцију су остале и то у следећим фазама:

1. при одлучивању да ли ће се нешто набавити. Ту се тешко може контролисати сврсисходност набавке јер је то и тешко процењиво. При томе, спецификацијом робе (тражење одређених карактеристика - тј. да роба мора задовољити одређени стандард) може се отклонити конкуренција јер тај стандард може да задовољи само један или одређени број произвођача. При томе, у поступку одабира тешко је одлучити да ли предност треба дати квалитативној или квантитативној методи. Субјективна процена је неминовна, што отвара могућност за корупцију. 
2. При спецификацији робе често се захтева одређена стручност па се тај посао поверава уском кругу људи. Њихову слободну (стручну) процену тешко је оцењивати и контролисати.

3. При оцењивању (бодовању) пондера ситуација је још сложенија. Процена је субјективног карактера а када се ради о оцени стручне способности понуђача, врло је тешко законом прописати објективне критеријуме и начин бодовања. Тај део поступка је веома подесан за "легалну" корупцију.

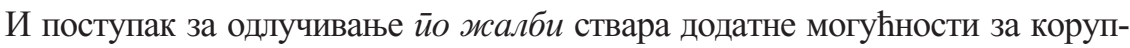
цију. Жалба веома успорава поступак и у том временском размаку може доћи до активирања побуда и тражње за корупцијом. Да би се поступак малих набавки убрзао, законодавац је дао могућност да се за набавку до 331.000,оо динара вредности (што се утврђује Законом о буцетиу уз обавезу израде плана) не мора расписивати тендер већ се набавка може вршити непосредном погодбом. Међутим и поред тако одређеног лимита могућност корупције није безазлена, напротив.

Поступак јавних набавки у обласиии одбране и унуиирашњих йослова и даље је "поверљив". Провера да ли је изабран најбољи понуђач практично је немогућа, па се са разлогом може претпоставити да се у овим случајевима може јавити одрећена корупција.

\section{5. Правосуђе}

Независно судство у односу на политичку (извршну) власт основни је услов његовог ауторитета и гаранција владавине права. „Прецизније речено, колико судство одолева настојању политичке власти, које није од јуче него је познато од памтивека, да га стави под своју директну или индиректну контролу зависиће степен поверења у њега од стране чланова друштвене заједнице.“(Vuković, 2007: 37) Национална стратегија реформе правосуђа усвојена је у априлу 2006. године. Циљ стратегије је означен као успостављање владавине права и правне сигурности како би се вратило пољуљано поверење грађана у правосудни систем. Стратегија је требала да буде заснована на принципима судске независности, транспарентности и ефикасности. Међутим, ниједно од ових назначених начела није остварено, шта више, могло би се рећи да је правна несигурност свакодневна појава (види Зиндовић, 2010:8). Фактичка несамосталност судске власти је практично озакоњена доношењем и формалних прописа, што очигледно представља "легалан" вид корупције.

Кроз историју судска власт је у Србији колико-толико формално уживала одређену независност. „Тековина владавине права и демократска процедура најнепосредније су везани за аутономију и независност судства и јасан су параметар културног достигнућа једне земље“ (Перовић, 2008: 94). Након петооктобарских промена ова су достигнућа на веома ниском нивоу. Формална генеза укида- 
Илија Б. Зиндовић, Владан Станковић, „Легализовани“ облици корупције у Србији...

ња судске независности, очигледно по налогу политике, ишла је поступно. Устав Републике Србије садржавао је начело о владавини права и троделној подели власти. У чл. 9. било је прописано да уставотворна и законодавна власт припада Народној скупштини, извршна власт припада Влади, а судска власт припада судовима. Закон о судовима Републике Србије $(1991,1992)$ у својим основним одредбама прописивао је да судска власт припада судовима као самосталним државним органима, да судови судску власт врше независно и да је судијска функција стална.

Након промена од 2000. године донет је нови сет закона и то: Закон о уређењу судова (2001), Закон о судијама (2001), Закон о седиштима и подручјима судова и јавних тужилаштава (2001) и Закон о јавном тужилаштву (2001). Чинило се да назначени закони представљају велики искорак у остваривању начела о независности судске власти. Усредствима информисања истицано је да они пружају основу за реформу правосућа, како у организационом смислу у циљу успостављања ефикаснијег рада судске власти, тако и у избору судија. Уверавано је да ће се судије бирати по стручном и никада више према политичком и страначком критеријуму.

Установљење Високої савеӣa йравосуђа требало је да означи значајан корак у афирмисању судске власти. Њихов задатак је осмишљен као стучно профилисање кадрова за правосуђе и предлагање за избор судија и председника судова законодавној власти. „Тиме је установљена претпоставка да се судије бирају по стручности, а не по припадности политичким странкама, што би резултирало непристрасности у раду судија.“ (Марковић, 2007: 695)

Међутим, у практичној примени није се много одмакло од прокламованих норми, па се стало са чекањем доношења новог устава. У чл. 17. ст. 1. Закона о Високом савету судства (2008) прописано је да тај државни орган одлуке "доноси већином гласова". Дакле и Устав и закон траже да Високи савет судства има све чланове. Представник из реда професора није уопште био изабран, а представника адвокатуре није предложило легално тело. Но и поред тога, Високи савет судства је одлучивао игноришући законске и уставне норме тумачећи их како му одговара. Све то је чињено тајно без могућности да се јавност информише о томе. У чл. 10. ст.1.Устава из 1990. године, постојала је одредба: "рад државних органа је доступан јавности". У Митровданском уставу из 2006. године такве одредбе више нема. Али и ако нема те одредбе, у чл. 1 Устава (2006) је прописано да је „Република Србија заснована на владавини права и социјалној правди, начелима грађанске демократије, људским и мањинским правима и слободама и припадности европским принципима и вредностима““. Сходно томе било је и неспојиво генерално искључити јавност из рада државног органа којем је Устав поверио административно управљање судском влашћу. Да би се озаконила неза- 
конитост у поступању Високи савет судства је донео Пословник о раду (2009) и у чл. 5. прописао: "седнице Савета затворене су за јавност", док је у чл. 12. прописано да су чланови ВСС дужни "да чувају тајност података које је Савет одредио тајним" и "да не откривају које информације се односе на процес доношења одлуке Савета". У другој половини 2009. године Високи савет судства спровео је реизбор свих судија а да ниједног неризабраног судију није позвао да се изјасни

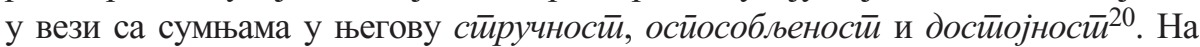
примедбу да такав поступак није транспарентан ВСС је правдао коришћењем дискреционог права. Међутим, такво тумачење ВСС се не може правдати дискреционим правом, јер то право ВСС није законом ни дато. То се пре може назвати злоупотребом овлашћења или "легалном" корупцијом. У даљој фази свог коруптивног понашања Високи савет судства је одбијао да нереизабраним судијама достави појединачну одлуку. Иако је Венецијанска комисија (чије мишљење у официјелним круговима има највећу правну снагу а у научним круговима највећи домен правног тумачења) у свом Мишљењу (број 528/09) о Нацрту критеријума и мерила за избор судија и председника судова у Србији од 12-13. јуна 2009. године, заузима став да "сваког постојећег судију са сталном функцијом (било да се пријављује или не за реизбор) требало би разрешити једино путем образложене одлуке, против које се може поднети жалба суду", Високи савет судства игнорише такво мишљење и упада у прави вртлог безакоња и корупције. Да не би остали без икакве правне заштите, а због ускраћеног права зајемченог уставом, више стотина нереизабраних судија Уставном суду подноси уставну жалбу против предпостављеног акта о нереизбору судија. Под притиском стручне јавности и коначно увидевши да таквим понашањем директно крши одредбе чл. 32. ст.1., 36. и 60. ст.4. Устава ${ }^{21}$ Високи савет судства, везано за реизбор, одлучује да донесе једну одлуку за све судије. Очигледно је да је овакав поступак био нелогичан и незаконит. Увидевши да ниједан жалилац не зна разлоге због којих му је престала судијска функција и како је постало очигледно да Уставни суд не може прихватити такав пропуст, након шест месеци Високи савет судства (под датумом од 14. 06. 2010) доноси и доставља, почев тек од октобра месеца 2010. године, појединачне одлуке за нереизабране судије. У тим одлукама разлози нереизбора за поједине судије били су више него апсурдни, наводили су се погре-

${ }^{20}$ Овакво понашање је било у директној супротности са чл.13.ст.1. Одлуке о утврђивању критеријума и мерила за оцену стручности, оспособљености и достојности за избор судија и председника судова (2009) где је прописано да „ Претпоставља се да судија који је биран по ранијим прописима и који у време избора врши судијску дужност, а пријавио се за избор у суд исте врсте, односно истог степена, испуњава критеријуме и мерила из ове одлуке“.

21 Чл. 32. регулише право на правично суђење, чл.36. право на једнаку заштиту права и на правно средство, а чл. 60. право на рад. 
Илија Б. Зиндовић, Владан Станковић, „Легализовани“ облици корупције у Србији...

шни подаци о резултатима рада, а у неким случајевима и измишљали разлози за нереизбор.

С обзиром да су и званичници Европске уније оштро реаговали на такав поступак Високог савета судства (да је било неправилности и да се исте морају отклонити), новоизабрани Високи савет судства, који чине и три ранија члана по функцији (председник Врховног касационог суда, министар правде и председник скупштинског одбора за правосуђе), не прихватајући нацрт Смерница које су урадили Друштво судија и ОЕБС и за које је добијена висока оцена Комисије ЕУ, дана 23.05.2011. године доносе своја Правила за примену Одлуке о утврђивању критеријума и мерила за оцену стручности, оспособљености и достојности и за поступак преиспитивања одлука првог састава Високог савета судства о престанку судијске дужности (2011). У тим Правилима су прописани строжији критеријуми од оних који су важили у време реизбора. Иако је упозоравано да се ради о подзаконском акту и да исти не може имати ретроактивно дејство званичници Министарста правде су све то одбијали. Каква се онда ревизија нереизабраних судија, са применом оваквих прописа и дискреционих овлашћења могла уопште и очекивати. Уставном суду је поднета иницијатива за покретање поступка за оцену уставности назначених правила, што је након скоро годину дана Уставни суд Србије прихватио и покренуо поступак за оцену уставности.

Новоизабрани ВСС је започео рад везано за преиспитивање приговора нереизабраних судија али се показало да исти ради под притиском извршне власти. Дана 23.12.2011. године један члан ВСС из реда судија подноси оставку са образложењем да је ВСС онемогућен у вршењу својих надлежности да се ради под притиском и да он...не жели да учествује у свему томе. Но и поред тога ВСС је дана 23.11.2011, 01.12.2011 и 08.12.2011. године заседао и одлучивао о приговорима судија. При томе није узето у обзир да ВСС не ради у прописаном саставу тј. да нема довољан број чланова, јер је Агенција за борбу против корупције констатовала да код члана ВСС из реда професора постоји сукоб интереса, јер је уједно и декан правног факултета, да не може бити члан ВСС те да му функција члана ВСС престаје по сили закона дана 23.12.2010. године. Скупштина Србије је требала на седници то само да констатује. Међутим, на седници од 29.12.2010. године Скупштина Србије је одбила да констатује да назначеном члану ВСС престаје функција по сили закона. 22 Очигледно је да је Народна скупштина уместо силе закона одлучила да примени право силе. Да ли је овде уопште и потребно коментарисати да је у питању „легална“ корупција и то највишег законодавног органа. Овим је Народна скупштина прекорачила своја законска овлашћења и

${ }^{22}$ Као професор на Правном факултету, из моралних разлога, било је за очекивати да тај члан ВCС поднесе оставку на ту функцију, што се није догодило. 
озбиљно нарушила правни поредак Србије. Ако овако поступа законодавни орган, како очекивати од појединаца да поштују закон. Под плаштом реизбора (односно лустрације) одстрањене су непослушне судије, а ,један од видљивих видова притиска на судство су јавна коментарисања одлука судова од стране политичке власти или њој блиских појединаца“ (Вуковић, 2007: 40).

\section{3. Закључак}

На основу свега изложеног долазимо до закључка да "легални" облици корупције представљају одређене незаконите поступке и радње власти које додатно воде појави друштвене аномије и неминовно воде у деструкцију институционалног система, повећавају корупцију и криминал у друштву, умањују правну сигурност, крше или изврдавају законом предвићене демократске процедуре, спречавају даљи економски раст и свеопшти развој друштва. "Легални" облици корупције јављају се у форми: узурпације власти (узимања онога што им не припада), злоупотребе овлашћења (прекорачења онога што им припада), заобилажењем законом утврђених процедура, непредузимањем радњи (тзв. пасивизација) које су били дужни да предузму на основу закона. Све побројано јасно указује на повратну спрегу и неспоран узајамни однос између корупције и аномичних стања друштвене антропије који би морали, коначно, задобити карактер противправности (инкриминацију), како би се корупција сасекла, а друштво ушло у фазу оздрављења, економског раста и свеукупног друштвеног развоја. ${ }^{23}$

\section{Предлої мера}

Промена постојећег стања, по нашем мишљењу, могућа је индиректним путем, изменом постојећих законских и подзаконских прописа из ове области а у складу са европским стандардима. Имајући у виду не само законску већ свеопшту, нормативну, димензију ових појавних облика, ваљало би већу пажњу посветити и моралним нормама које настају у процесу социјализације: васпитањем, образовањем, културном антиципацијом и сл. Непходно је предузети дубоке институционалне реформе, којима би процеси рефеудализације, корпоративизације и котеризације били не само обустављени, већ и искорењени. Без јасних правила игре које налаже тржишно надметање, није могуће изаћи на крај са овим патогенима, који доводе до непримереног богаћења и спречавају тако неопходну проходност најбољих у једном друштву.

23 "Нарушавање владавине права, односно правне државе подрива темеље тржишне привреде, ограничава тржишне трансакције, омета специјализацију и друштвену поделу рада и на тај начин онемогућава успостављање економски ефикасне алокације ресурса." (Беговић, 2005: 217) 
Илија Б. Зиндовић, Владан Станковић, „Легализовани“ облици корупције у Србији...

\section{ЛИТЕРАТУРА}

Anomie (1970). La sociologie. Paris: Centre d' Étude et de Promotion de la Lecture.

Anomija (1977). M. Bosanac, O. Mandić, S. Petković (prir.), Rječnik sociologije i socijalne psihologije, Zagreb: Informator.

Anomija (1982). Sociološki leksikon. Beograd: Savremena administracija.

Anomija (2007). A. Mimica, M. Bogdanović (prir.), Sociološki rečnik. Beograd: Zavod za udženike.

Беговић Б, (2005). Економске последице корупције у правосућу. Социолошки йрейлед, 2/2005:

197-220, Београд: Институт друштвених наука

Беговић, Б. и др. (2007). Коруйиија у Србији иеей іодина касније. Београд: Центар за демократске студије.

Вуковић C, (2001). Раширеност и осуда корупције у Србији. Социолошки йреїлед XXXV (12): $3-18$.

Вуковић C, (2004). Корупција између права и морала. Социолошки йреїлед XXXVIII (4): 507526.

Vuković, S (2005). Pravo, moral i korupcija. Beograd: IDN, Filip Višnjić.

Вуковић, С. (2007). Транзиција и коруйција, Београд: Рад.

Grk, S. (2004). Dimenzije propadanja Srbije. Poslovna politika (6): 8-14.

Đurić, A. (2009). Korupcija u Srbiji. Ekonomika (6): 54-69.

Jovanović, P. (2001). Anatomija korupcije. Beograd: Transparency International Serbia, Beograd.

Jovašević, D. (2011). Krivična odgovornost za primanje i davanje mita. Revija za kriminologiju $i$ krivično pravo (2-3): 357-372.

Kim, Kwang-ki (2003). Order and agency in modernity - Talcott Parsons, Erving Goffman, and Harold Garfinkel. SUNY Press.

Korupcija (1975). Ekonomski leksikon. Beograd: Savremena administracija.

Korupcija (2007). A. Mimica, M. Bogdanović (prir.), Sociološki rečnik. Beograd: Zavod za udženike.

Korupcija (2009). < http://wmd.hr/rjecnik-pojmovi-k/web/korupcija > 12. фебруар 2012.

Корупција (2010). < http://sr.wikipedia.org/wiki/Kopyüuија > 12. фебруар 2012.

Lizeth, P., Mariluz L. (2011). Judicial Corruption in the Peruvian Judicial System - Ways to resolve the problem by applying the Economic Analysis of Law. University of Toronto.

Legradić, R. (1968). Sociologija prava. Beograd: Naučna knjiga.

Lukes, S. (1985). Emile Durkheim, his life and work - a historical and critical study. Stanford University Press.

Марковић, В. (2007). Независност судства. Правни жиивой LVI (13): 693 - 701.

Mény, Y. (1996). Corruption and its analysis ambiguities, problems and divergences. International Social Science Journal XLVIII (3): 309-320.

Милосављевић, 3. (2011). Непримерено богаћење и корупција у Србији. Полийичка ревија (4): 173-198.

Nikolić, G. (2011). Korupcija - promene globalne pozicije Srbije u poslednjoj deceniji. Međunarodna politika (1144): 19-35.

Nye, J. (1967). Corruption and Political Development - A Cost-Benefit Analysis. American Political Science Review 61 (2): 417-427. 
Одлука о утврђивању критеријума и мерила за оцену стручности, оспособљености и достојности за избор судија и председника судова ( 2009). Службени йласник РС (49)

Перовић, С. (2008). Слобода и природно право. Правни живой LVII (1-2): 31 - 99.

Пословник о раду Високог савета судства (2009). Служсбени йласник РС (43).

Правила за примену Одлуке о утврђивању критеријума и мерила за оцену стручности, оспособљености и достојности и за поступак преиспитивања одлука првог састава Високог савета судства о престанку судијске дужности (2011). Служббени іласник РС (35).

Радбрух, Г. (1980). Филозофија йрава. Београд: Нолит.

Ракић, М. (2010). Корупција као одраз стања безбедности Републике Србије. Полийичка ревиja (3): 359-377.

Станковић, В. (2010). Друштвене елите у Србији - преображај и проходност у последњих двадесет година. Национални иниеерес (3): 469-490

Станковић, В. (2011). Утицај конфесионално-хришћанског чиниоца на корупцију. Срйска йолиииичка мисао (2): 57-76.

Станојевић, Ј., Д. Димовски (2011). Корупција у јавним институцијама. Социјална мисао (4): 97 113.

Шуковић, Д. (2006). Корупција у Србији и Европске интеграције. Економски видици (2): 257266.

Tanzi, V. (2000). Policies, institutions and the dark side of economics. Edward Elgar Publishing.

Тартаља, С. (1976). Скривени круі - кружење елийа. Београд: Председништво ССОЈ.

Устав Србије (2006). Служббени йласник РС (98).

van Duyne, P. C., E. Stocco, M. Milenović (2009). Korupcija u Srbiji - jedinstvena ili zajednička balkanska bolest. Temida (4): 29-58.

Заграђанин, В. (2009). Коруйција и јавне набавке. Нови Сад, Београд: Правни факултет за привреду и правосуђе.

Закон о спољнотрговинском пословању $(2000,2001,2005)$. Службени йласник РС (73/2000, 23/2001, 101/2005).

Закон о заштити конкуренције $(2005,2009)$.Службени гласник РС (79/2005, 51/2009).

Закон о приватизацији ( 2001, 2003, 2005, 2007, 2010).Службени йласник РС (38/2001, 18/2003, $45 / 2005,123 / 2007,30 / 2010)$.

Закон о привредним друштвима (2004). Службени йласник РС (125/2004).

Закон о јавним набавкама (2003, 2004, 2005) Службени илласник РC (43/2003, 55/2004, 10/2005).

Закон о високом образовању (2010) Службени иласник РС (44/2010).

Закон о судовима Републике Србије $(1991,1992)$. Службени илласник РС (46/1991, 60/1991, 18/1992, 71/1992).

Закон о уређењу судова (2001). Службени йласник РС (63/2001).

Закон о судијама (2001). Службени йласник РС (63/2001).

Закон о Високом савету судства ( 2008 ).Службени иллсник РС (116/2008).

Закон о изменама и допунама Закона о Високом савету судства (2010), Службени йласник РC $(101 / 2010)$.

Закон о седиштима и подручјима судова и јавних тужилаштава (2001). Служсбени йласник РС $(63 / 2001)$.

Закон о јавном тужилаштву (2001). Службени илласник РС (63/2001).

Зиндовић, И. (2010). Мейодолоїија и иеехника израде судских одлука. Београд: Пословни биро. 
Илија Б. Зиндовић, Владан Станковић, „Легализовани“ облици корупције у Србији...

Ilija Zindović

Summary

University of Business Academy

Novi Sad

Vladan Stanković

Institute for political studies

Belgrade

\section{"LEGALIZED" FORMS OF CORRUPTION IN SERBIA - ANOMICAL STATE OF SOCIAL ENTROPY}

The subject of this research will be phenomena of "legalized" form of corruption. The name we gave to all those forms of social behavior that anomical escape incrimination, are not defined precisely by laws, a cause of increasing social anomie, and ultimately lead to destruction, entropy and disintegration of society. The study will include a spatial framework of the Republic of Serbia, during the time interval since 2000. onwards, with a look in the 90's of the last century, and follows a period of transition from socialism, and post-socialism, to this wild and unrestrained form of capitalism. Methods that are used in the study were: a sociological method (observation, comparative method), Legal (dogmatic-normative, method of the target interpretation) and the logical method of generalization and concretization. The study aims to highlight the manifestations of corruption that have for various reasons are not criminalized, and thus indicate the harmfulness socialanomical conditions that are directly related to the entropy of society in which we live. After that follows the proposal of measures to remove these harmful emergent phenomena in the border area of?? sociology and law.

Key words: corruption, social anomie, institutions, justice, Serbia 